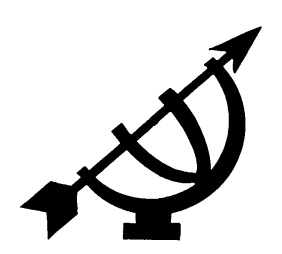

\title{
Law and individuality
}

\author{
D.F.M. Strauss \\ Dean's Office \\ Faculty of the Humanities \\ University of the Free State \\ BLOEMFONTEIN \\ E-mail: dfms@cknet.co.za
}

Abstract

\section{Law and individuality}

The main contours of the history of philosophical and scientific conceptions of law and individuality are portrayed. This includes an account of perspectives and views found in ancient Greece, the Graeco-Roman world, the medieval speculation and, via the Renaissance, in early modern developments that were continued in the Enlightenment era, in Romanticism and historicism, and were eventually manifested in the linguistic turn. What is important for a proper understanding of modern law conceptions is an acknowledgement of the all-pervading influence of modern nominalism. This orientation was characterised by employing two related distinctions, namely the distinction between conceptual knowledge and concept-transcending knowledge, and that between rationalism and irrationalism. From a systematic point of view, various aspectual terms provide a frame of reference for the idea of a law of nature as a compound basic concept of science. Special attention is given to the nature of normative principles and physical laws. In the last part of the article, these perspectives are applied to a brief assessment of differences and similarities in the thought of Dooyeweerd and Vollenhoven.

\section{Wet en individualiteit}

\section{Opsomming}

Hierdie artikel lê die hoofkontoere uit die geskiedenis van die besinning oor die aard van wet en individualiteit bloot. Dit omspan perspektiewe en sienings uit antieke Griekeland, die Grieks-Romeinse wêreld, die midddeleeuse spekulasie en die Renaissance. Vroeg-moderne ontwikkelinge word opgevolg tot by die Verligting, die Romantiek, die historisme en die uit- 
eindelike wending na die taal. Van besondere betekenis vir die verstaan van moderne opvattings oor die aard van ' $n$ wet is die alles-deurdringende invloed van die moderne nominalisme - 'n oriëntering wat deur twee parallellopende onderskeidings gedefinieer is, naamlik die onderskeiding tussen begripskennis en begripstransderende kennis en dié tussen rasionalisme en irrasionalisme. Vanuit 'n sistematiese perspektief is verskillende modale terme gebruik om rekenskap te gee van die idee van 'n wet as 'n saamgestelde grondbegrip van 'n wetenskaplike dissipline - met besondere verwysing na fisiese wette. In die laaste afdeling van die artikel word 'n samevattende beoordeling van verskille en ooreenkomste in die denke van Dooyeweerd en Vollenhoven gegee.

\section{Orientation}

The terms in the title are practically as old as Western philosophy itself. For this reason, we first have to pay attention to the historical background of the notion of law, after which an account will be given of the history of the idea of individuality, followed by a systematic appraisal of the connection between law and individuality.

\section{Contours regarding the history of the concept of law}

The original idea of law (nomos) had a broad scope. Hesiod accepted the idea of nomos by Zeus and it has to direct itself as an art of life towards the human being in general (Hesiod, 1962:276 ff.; see Plumpe, 1974:494). This initial understanding of law (logos) is not restricted to any domain of reality - it encompasses the world as a whole. Even when Anaximander says that there is a law of justice, that by virtue of the order of time brings everything that took on a limited form back to its formless origin (Diels \& Kranz, 1959/1960: B. Fr.1), the idea of justice and injustice (dike and adikias) still do not merely apply to jural relationships, but to the cosmos as a whole. Heraclitus advanced the idea of a divine law ( $Q$ e io" nomo") as principle of the universe, the world logos (logo") (Diels \& Kranz, 1959/1960 Heraclitus B. Fr. 30 ff.). Democritus added the idea that the commands of nature are necessary (Plumpe, 1974:494).

In early Greek philosophy, the individuality of the human being was eventually also related to the world order - knowing the self opened the way to an understanding of the logos of the world. Heraclitus believed that discovering "my real self " will enable an understanding of "the logos which is the real constitution of everything else as well" (Guthrie, 1962:419). 
Although Greek political philosophy in Plato and Aristotle eventually restricted the notion of law to the political sphere (the Greek polis or city state), Cicero, in reaction to the idea that law is fluid and changeful, advances the view that all positive law must be understood in terms of fixed legal principles, flowing from an ethical world order. The preferred designation of this order is found in the notion of a natural law, a lex naturalis. 1 This idea of natural law was given in varying accounts, such as lex naturae, lex naturalis, ius naturae, and ius naturale, as well as those in expressions such as vera lex (true law), summa lex (supreme law), lex divina et humana (divine and human law), and so on (see Van Zyl, 1989:297-298). Cicero conceived a universal law that was assumed to be immutable, incorruptible, non-arbitrary, and valid per se. Jones points out that, flowing from divine reason, Cicero regards the ius naturale to comprise

those half-legal, half-ethical rules that express the principles of human justice, because they have a bearing upon the relations of men living in society and upon their duties to one another and to the gods (Jones, 1956:99).

Derived from the space metaphysics of the school of Parmenides, medieval philosophy contemplated an order of being that finds in God, as the ipsum esse, its culmination point. The realist legacy regarded Plato's theory of ideas ${ }^{2}$ as its first starting point. During the early Middle Ages (via neo-Platonism), these eternal (super-sensory) forms were transformed into creation ideas inherent to the divine mind (realistic metaphysics called them ante rem). Aristotle, with his secondary substance, focused on the orderliness (lawfulness) of reality, i.e. the universal way in which creatures show that they conform to an order for their existence. 3 The view of universalia

1 Compare, in this connection, his work "De republica" (Book 3, chapter 22; Cicero, 1978) as well as his "De Officiis" (Cicero, 1991).

2 Plato actually discovered God's steadfast law as order for creatures but metaphysically elevated it to his intelligible realm.

3 Aristotle started with a purely individual primary substance, but in order to save conceptual knowledge, he introduced the universal substantial form of things (cf. Aristotle, 2001:7 ff.; Cat. $1 \mathrm{ff}$.). His example is that when this house passes away, it is not house-ness that passed away (Aristotle, 2001:807: "the being of house is not generated, but only the being of this house"; Metaph.1039 b 2425 ). We shall argue below that in being this or that, concretely existing entities (in a universal way) show that they are subject to a universal order for their existence. 
in re in medieval realism continues this Aristotelian legacy. Next to universalia ante rem (platonic ideas) and universalia in re, medieval realism also accepts universal concepts within the human mind (universalia post rem).

During the transition from the Medieval era to the Renaissance, nominalism emerged as a movement radically opposing the realistic metaphysics of the medieval period. William of Occam (1290-1350) assigned primacy to the will in reaction to the preference of Thomas Acquinas for the primacy of the intellect. However, the difference between Thomas Aquinas and Occam is their respective views on universality and individuality. Occam's nominalism does not allow for anything universal outside the human mind (Occam, Summa logicae I, 14). Yet, according to him, science is concerned with universals within the human mind. This nominalistic orientation is explored by the main representatives of modern philosophy. Descartes (1965: part 1.58), for example, considers number and all universals as mere modes of thought.

The fact that laws were indeed traditionally viewed as universal (in an ontic sense) now caused a problem. If there is no universality outside the human mind, an alternative understanding of the status of laws is required. How is it possible to subsume a multiplicity of individual things in reality to the universality of a law if there is nothing universal in an ontic sense?

Much later, the first element of this problem caused the demise of the positivist philosophy of science. Leave aside for a moment the status of a law ("ontic" or "mental"); its supposed universality seems to be at odds with the limited number of instances that can actually be checked through (experimental) human investigation. It is known that Kant, early in his intellectual development, was strongly influenced by Leibniz. Therefore, the claim by Bennett, namely that we should "not credit Leibniz with any Kantian insight about the need for intellectual structure" is a little far-fetched (Bennett, 1974:37). Almost anticipating Kant's criticism of Hume's empiricism, Leibniz, more than thirty years before the first appearance of Hume's $A$ treatise of human nature (1739 - his An inquiry concerning human understanding appeared in 1748), wrote in his New essays:

Now all the examples which confirm a general truth, whatever their number, do not suffice to establish the universal necessity of that same truth, for it does not follow that what has happened will always happen in the same way (quoted from Stich, 1975:45, cf. Kant, 1956 [1787]:B:5). 
According to Kant, the matter of experience lacks order, it is chaotic. It is only ordered through the sensory forms of intuition (space and time) and brought to unity by applying the categories of understanding: "The categories are conditions of the possibility of experience, and are therefore valid a priori for all objects of experience" (Kant, 1956 [1787]: B; 161). This entails that "[C]ategories are concepts which prescribe laws a priori to appearances, and therefore to nature, the sum of all appearances" (Kant, 1956 [1787]: B; 163).

In this way, Kant "solved" the above-mentioned problem: if there is no universality outside the human mind (as nominalism claims), then this vacancy has to be taken over by human understanding, with its universal concepts. Kant does not hesitate to state this extreme (subjectivist) conviction: "Understanding creates its laws (a priori) not out of nature, but prescribes them to nature" (Kant, 1969 [1783]:2, 320; par. 36). 4 Human understanding was thus promoted to become the (a priori and universally valid) formal law-giver of nature. 5

Yet this position soon had to suffer from the relativity introduced by historicism, with its new appreciation of unique and individual historical events - this was emphasised during the early 19th century.

By and large, the 18th century may be characterised as the age of Enlightenment in terms of its emphasis on the universality of conceptual knowledge (identified with what was assumed to be rational). The scope of the law of causality, for example, was supposed to be universal, and the same applies to Kant's categorical imperative - pursue only a maxim through which one at once will, that it thus may become a universal law (see Kant, 1786:52).

$4 \quad$ More than a hundred years before the linguistic turn emerged at the beginning of the 20th century, Herder criticised Kant's Critique of pure reason for neglecting language. Herder made the switch from thought to language, evident in his statement that the human being is a creation of language ("Der Mensch ist ein freidenkendes, thätiges Wesen, dessen Kräfte in Progression fortwürken; darum sei er ein Geschöpf der Sprache!" - Herder, 1978:73)

5 Wittgenstein continues this Kantian view when he says that everything outside logic is accidental (i.e. not subject to law), and that the exploration of logic means the exploration of everything that is subject to law (Wittgenstein, 1966: 6.3: "Die Erforschung der Logik bedeutet die Erforschung aller Gesetzmäßigkeit. Und außerhalb die Logik ist alles Zufall".) Even an element of Kant's accent on understanding as the a priori formal law-giver of nature is continued, for Wittgenstein says that the law of causality is not a law, but the form of a law (Wiltgenstein, 1966:6.32), and likewise that the law of conservation is the a priori possibility of a logical form (Wiltgenstein, 1966:6.33). 
An increasing sensitivity to the reality of individuality and what is unique in romanticism at the turn of the 18th to the 19th century, contributed to the rise of historicism - a philosophical trend attempting to turn away from the universalities of human reason by taking seriously what was considered the inherently changeful and irrepeatable: historical reality in its uniqueness and individuality. Initially it did seem as if this transitional process would succeed in maintaining a sound balance between universality and individuality. According to Meinecke, modern historicism even pursued the task of understanding both the individual structures of historical humanity and the general timeless laws-for-life in their universal coherences.

When Meinecke characterises the highest worldview achievement of Goethe in terms of a balance between heraclitean and eleatic thought (eternal becoming and eternal being), 6 it still seems as if Goethe attempted to do justice to both universality and what is individual. His need for eternal laws manifests the influence of neoPlatonism and it reveals an element of continuity with Enlightenment. Yet, in the final analysis, his appreciation of the universal experienced a twist in the direction of what is changeful and individual. Meinecke (1965:504) writes:

Goethe's concept of law was totally different from that of the Enlightenment, completely free from mathematical ingredients.

Then Meinecke (1965:504) quotes Gundlof:

Goethe's laws themselves are individuals, delicately, elastic precisely though constantly mobile, mystical inner form forces. ${ }^{7}$

Niebuhr, Leopold von Ranke's tutor, demonstrates the transition from the 18th to the 19th century in a remarkable way. In opposition to Plato, who acknowledges only knowledge directed at the true (static) being of things as worthwhile, Niebuhr is convinced that only historical change provides a basis for sound knowledge (see Cassirer, 1957:237). In opposition to the deification of universal (conceptual) knowledge during the 18th century, we are brought into

6 "So besteht Goethes höchste Weltanschauliche Leistung darin, daß er heraklitisches und eleatisches Denken, ewiges Werden und ewiges Sein veschmolz 'Dauer im Wechsel'.' (Meinecke, 1965:503.)

7 "Goethes Gesetze sind selbst Individuen, dehnbar feine, dem immer beweglichen eben geheimnisvoll innewohnende Formkräfte." (Meinecke, 1965:504.) 
contact with the importance of historical change - indeed with the rise of modern historicism.

The supposedly universally valid construction of reality by the human subject eventually became a victim of the relativistic consequences of this historicism. Combined with the so-called linguistic turn (by the end of the 19th century and the beginning of the 20th century), the outcome of this process settled for a personally or socially constructed world - each person or each society constructs its own unique life-world. If the emphasis falls upon language, the additional qualification is that every person or society gives its own meaning to the world.

Before we proceed to a systematic perspective, a number of crucial issues in the history of reflection on the nature of individuality ought to be highlighted as well.

\section{The problem of individuality}

Since Greek philosophy, a key problem was to find what became known as the principle of individualisation. Aristotle, for example, claimed that matter is the principle of individuality: "But all things many in number have matter." (Aristotle, 2001:884; Metaf. 1074 a 34.) We noted above that, from the opening sections of Aristotle's work on categories, it is clear that he based his starting-point on the idea of a strictly individual primary substance. Here he defines substance "in the truest and most definite sense of the word" as "that which is neither predicable of a subject nor present in a subject" (Aristotle, 2001:9; Cat. 2 a 11-13). The secondary substances, however, are universal (Aristotle, 2001:9; Cat. 2-4) - species and genera are universal.

Later on, in neo-Platonism, we find that priority is assigned to what is universal while acknowledging that what is individual cannot be conceived (see Plotinus, 1956: Enn. VI. 3.9.36 and Enn. VI. 2.22). Interestingly Simplicius already distinguished between the numerical one and what is individual (Kobusch, 1976:302). ${ }^{8}$ Ammonios Hermeiu influenced the distinction between the four "complexions" found in the thought of Boethius: substantia universalis; substantia

8 Implicitly this highlights the difference between what we will designate below, from a systematic perspective, as a conceptual use of numerical terms (the "numerical one") and a concept-transcending use of numerical terms (the idea of an individual thing). 
particularis; accidens universale; accidens particulare. Where singularity indicates similarity for Richard von St. Victor, individual substantiality is found only in one individual, and therefore cannot be shared by multiple substances, and for this reason it is "incommunicable" (see Kobusch, 1976:303).

The commonly held view during the Middle Ages (shared by Bonaventura, Thomas Aquinas, Henry of Gent and Duns Scotus) was that an individual is undivided (the literal meaning of individuum), while at the same time being separated from everything else (see Oeing-Hanoff, 1976:306). The term undivided reflects the wholeness (one-ness) element of the whole-parts relation, and in addition to the one, it entails the many separated undivided ones (wholes). In other words, the one and the many are situated within the context of the idea of wholeness and distinctness.

The employment of the whole-parts relation acquired a closer specification in the thought of Boethius, who distinguished between homogeneity and heterogeneity - every part of an individual drop of water is still water (physical homogeneity), whereas it is not true that every part of a horse is a horse (biotic heterogeneity) (see OeingHanoff, 1976:306).

Leibniz continued the view of Aristotle by inverting the idea that individuality falls under general concepts. Rather, one should say that what is universal is contained or embraced in what is particular and individual (see Borsche, 1976:310). When he determines the individual substance in his Monadology, Leibniz assumes an original self-activity prevailing in a state of continuous change (appetition) (Borsche, 1976:311).

In close connection with the early Romantic switch from rationalism to irrationalism, Herder affirms that the "deepest foundation of our existence is individual" (Herder, 1877: vol. 2, 207). In a letter to Lavater, Goethe mentions the saying "Individuality is ineffabile" (Borsche, 1976:312). According to Fr. Schlegel, individuality is never completed, since it is always involved in continuous becoming ("beständiges Werden"). What is essentially incomplete is infinite, and therefore individuality is eternity within the human being, and only it can be immortal (Borsche, 1976:315).

Goethe played with the inseparable connection between individuality and universality. His answer to the question, what is universal? (Was ist das Allgemeine?) is: the individual instance; and his answer to the question, what is particular? (Was ist das Besondere?) is: 
millions of instances (see Von Weiszäcker, 2002:212). Yet this does not mean that Goethe actually maintained a balance between universality and individuality, because according to him, in the words of Von Weiszäcker, the Gestalt is not rooted in the law, for the law is rooted in the Gestalt (Von Weiszäcker, 2002:209).

\section{Systematic considerations}

It is striking that the battlefield between universality and individuality is served by our basic intuitions of number and space. The idea of being distinct (at least partially) pre-supposes the discrete meaning of number, while understanding universality pre-supposes the spatial awareness of everywhere. Of course the numerical point of entry - or mode of explanation - can be complemented in yet another way by the spatial angle of approach, namely when its articulation at once also highlights numerical analogies within space. 9 This happened during the later Middle Ages, in which we noted that the term undivided reflects the one-ness element of what we now identify as the spatial whole-parts relation.

\subsection{Knowledge based upon universality}

Although the nature of individuality surely exceeds the limits of the numerical (and all other) aspect(s) of reality, it is undoubtedly also the case that in our employment of the idea of individuality, our arithmetical intuition is prominent. What is perhaps even more important is that, because concepts are formed on the basis of what is universal (universal properties), conceptual knowledge of what is individual is impossible. Even Scholasticism was faithful to the conviction that whatever is individual is inexpressible (omne individuum est ineffabile). However, this limitation of conceptual knowledge led to a reductionist view of knowledge, one in which knowledge is identified with conceptual knowledge. Nontheless, we do have knowledge of things in their individuality; the only requirement is to realise that this kind of knowledge transcends the scope of knowledge mediated by universality, i.e. conceptual knowledge. The

9 Within the philosophy of Dooyeweerd and Vollenhoven, the coherence between the multiple irreducible aspects of reality is accounted for by referring to these interconnections as modal analogies (retrocipations and anticipations). In this context, the original numerical meaning of succession (one, another one and so on without end, endlessly) is turned "inwards" by the spatial meaning of continuity - seen in the endless divisibility of a continuous whole. 
identification of knowledge with conceptual knowledge may be designated as rationalistic.

The kind of knowledge involved in approximating what is unique, contingent and individual transcends the limits of universality (concepts) and should therefore be acknowledged for what it is: concepttranscending knowledge. Nicolai Hartmann once explained the Kantian notion of a Grenzbegriff in a striking way. He says that the notion of an unknowable "thing-in-itself" (Ding an sich) still requires a thought-form, through which it is thought of as unknowable - this is what a Grenzbegriff intends to capture.10 Without buying into the role of the so-called "thing-in-itself" in the philosophy of Kant (cf. the critical remarks made in Strauss, 1982:133, 141-143), it is important to leave room for a "form-of-thinking" that accounts for knowledge transcending the limits of concept-formation.

In his work on logic and epistemology, De Vleeschauwer (1952:213) explicitly mentions what he calls the "individual delimitation". He writes that the domain of the "individual" is one where our intellectual capacities must fail. His own nominalistic affinities are evident in his view that there are only individual things and processes. He holds that, in spite of all similarities between entities and processes, there will always be an irreducible kernel of individuality, which causes one thing to be different from another. Science, with its directedness towards the universal has serious difficulties with its inclination to know what is individual - because "knowledge of what is individual is simply impossible" - something about which philosophy, according to De Vleeschauwer (1952:213), had clarity since its inception. In other words, De Vleeschauwer adheres to both the nominalistic denial of universality outside the human mind and the rationalistic identification of knowledge with conceptual knowledge.

\subsection{Knowledge exceeding universality}

From what has been argued thus far, it is clear that the relation between law and individuality at least in one sense runs parallel to the distinction between universality and individuality. Whereas we have pointed out that the notion of universality cannot conceal that it is derived from the meaning of the spatial aspect - the awareness of

10 Cf. Hartmann (1957:311): "Denn bei Kant ist es nicht so, dass etwa das Ding an sich bloss Idee wäre; umgekehrt, da wir das Ding an sich nicht erkennen ..., wohl aber denken können, so muss es eine Denkform, eine Art des Begriffs geben in der es - eben als unerkennbares - gedacht wird. Das ist die 'Idee'." 
everywhere - the situation with knowledge of what is individual is more complicated.

We have already suggested that a knowledge of what is individual exceeds the confines of conceptual knowledge. Yet we can specify what is at stake in more precise terms. Consider for a moment how we can apply our basic intuition of number, space, movement and energy operation in the following case. Think of the quantitative properties of a cultural entity (like a chair), of its size and shape (spatial), of its relative speed (motion) and of its typical physical characteristics (its strength). In every instance, the terms we have employed inevitably have a universal scope. This means that, whenever any person looks at a chair through the gateway of these different (ontic) points of entry, ${ }^{\mathbf{1 1}}$ the terms generated are used in a conceptual way. As long as we restrict the use of such terms to the respective ontic domains (modes of explanation), this conceptual focus will always be present. This is actually the case with all our entitary-oriented everyday concepts (just think of our concepts of entities such as planets, houses, chairs and human beings). If we designate the terms employed to describe the way in which entities function within various aspects of reality as modal terms (see Strauss, 2000:26-28, 32-36), then a distinction ought to be drawn. When modal terms are used to refer to entities that function within the confines of particular modes of being, they are employed in a conceptual manner. However, whenever a modal term is put in service of referring to whatever exceeds the limits or boundaries of such an ontic domain, then we encounter a concept-transcending use of such a term - also designated as an idea-use of such terms.

For example, while merely exploring our quantitative intuition, one can speak of a chair in its totality, including all its properties. Linguistically, this is expressed by referring to its individuality, its uniqueness, its being distinct. The original quantitative meaning of number (discrete quantity) - captured as a "primitive term" in axiomatic set theory $\mathbf{1 2}$ - is evident in these affirmations, and yet they are intended to refer to much more than the mere arithmetical aspect of the chair. They therefore indeed constitute idea-usages of modal numerical terms.

11 Which are then at once elevated to serve as epistemic modes of explanation.

12 Given in the plural of "elements of" or, in the case of Zermelo Fraenkel's set theory, "members of". 
Similarly, instead of speaking of the sizes and dimensions of a chair, one may use our intuition of the original meaning of spatial extension to speak of all facets of the chair - in which case one may refer to the chair in its totality. Once again, it is clear that the term totality - in spite of its spatial descent (see footnote 9) - refers to much more than merely the spatial aspect of the chair. It constitutes therefore - in terms of the distinction suggested concerning the two-fold usage of modal terms - another example of an idea-use of such terms, in this case spatial ones.

Modern phoronomy (the pure science of movement) understands motion in its original sense as uniform flow, without the need of any causes (as Aristotle believed). This kinematic intuition of constancy, when used in an idea-context, provides us with the idea-knowledge of the identity of an entity - its relative constancy amidst all changes - where the latter term finds its seat in the physical aspect of energy operation. The operation of energy always causes certain effects, and in this sense never leaves anything the same, i.e. identical. Therefore, the word change can also be employed in an ideacontext. But because the idea-meaning of constancy (consonant with the idea of identity) and the idea-use of the term change stem from two irreducible modes (detecting changes always presupposes constancy), it is not contradictory to use both ideas concurrently.

By expanding our view, we can indeed highlight the four most basic idea-statements that philosophy can formulate about the universe and once again we have to realise that these statements do not contradict each other, but rather entail and complement each other:

- everything is unique;

- everything coheres with everything else;

- everything remains identical to itself; and

- everything changes.

Only if these statements did not rest upon irreducible modal points of entry, would they have been contradictory.

At this point we may unite the main contours of our historical overview by pointing out that most of the issues mentioned converge towards an understanding of the role of the four aspects underlying the last-mentioned four idea-statements about reality. In fact, we have seen that these aspects served as points of entry in the history of reflection on law and individuality. Ultimately no view on law and 
individuality can side-step the first four modes of explanation of the world - for in both instances, one encounters a mixture of conceptual terms and a concept-transcending usage of modal terms. In order to articulate this claim, we now focus on the nature of natural laws.

\subsection{The concept of a normative principle and a natural law}

Cassirer mentions another element in the ancient Greek understanding of law - namely that nomos constitutes a principle of ordering, through which motion and the diversity within reality is arranged (Cassirer, 1911:375). During the early modern period, a reaction to the traditional Aristotelian-Thomistic view led to a natural scientific orientation that treated law within a predominantly relational coherence.

This new accent is an effect of a fundamental switch, one in which the focus is no longer on the substance of things (their essence), but merely on the way in which we experience them. Galileo is therefore no longer interested in the essence of things, but instead asks how they appear to us. What is revolutionary in his view, according to Herold, is that in the absence of thinking about essences (that proceeded from configurations of motion with distinct degrees of perfection) everything in principle is equal in the face of the law amply demonstrated in his remark that he did not study the pedigree of geometrical figures (see Herold, 1974:502).

Up to this point, the following features of natural laws surfaced: that they are necessary, ${ }^{13}$ they constitute an ordering in the sense of a relational coherence regulating motion and diversity within reality, and they are concerned with the how and not the concrete what of things.

During the early Modern era, these ideas developed within the context of the dominance of the modern ideal to understand the universe in terms of the (mathematical) natural sciences (also known as the natural science ideal). In the thought of Hobbes, science, understood as (natural) philosophy, opened the way to view individual things in relation to what is universal. His emphasis on the truth entailed in universal propositions (see Herold, 1974:503) reveals his nominalistic affinity that projected a human element into the univer-

13 Stegmüller considers it "Hume's great achievement to have banished the concept of necessity from the concept of cause" (Stegmüller, 1977:36). 
sality of a natural law. Particularly Newton $(1955: 1,15)$ started to explore more extensively the view that a law must be understood as a mathematically conceivable rule. While taking distance from the idea of a god-given law, the French Enlightenment, and particularly D'Alembert, derived from the relations between bodies governed by law the validity of the latter (Herold, 1974:505).

In the thought of Kant, the feature of necessity (Notwendigkeit) is accompanied by what he claims to be the universal-validity of a law. Insofar as rules are objective, they are designated as laws. We have seen that Kant derived these laws in an a priori way from human understanding that furnishes phenomena with the law to which they are subjected, i.e. understanding creates their lawfulness or lawconformity (Gesetzmäßigkeit) (see also Kant, 1781: A, 126). Kant's aim is to render comprehensible the "objective validity of the pure concepts a priori" of the categories of understanding (Kant, 1781: A, 128).

Hegel explores a further dimension in his science of logic, when he focuses on determining law (Gesetz) as what remains the same in what changes (Hegel, 1957:122). Cassirer assumes "ultimate logical invariants" that are not affected by their changing material content. He speaks of "identity and permanence" that lie "at the basis of scientific laws" (Cassirer, 1953:325). He actually came quite close to an understanding of the conditioning role of the first four modal aspects of reality in connection with an articulation of the nature of natural laws:

There is no objectivity outside of the frame of number and magnitude, permanence and change, causality and interaction: all these determinations are only the ultimate invariants of experience itself, and thus of all reality, that can be established in it and by it (Cassirer, 1953:309).

The "ultimate invariants of experience itself" are actually referring to the conditioning role of the most basic modal aspects of reality they are indeed those "determinations" co-responsible for the way in which we experience reality.

Without acknowledging the ontic structural configuration of reality, and in particular the ontic order of successive modal functions, we are left afloat without an anchoring guideline in our attempts to define the nature of natural laws. But once the underlying and conditioning role of these (ontic) modes of reality is acknowledged, 
another challenge faces theoretical analysis, namely to distinguish between elementary and compound basic concepts.

- Every scholarly discipline that finds its field of investigation delimited by a specific aspect of reality, employs basic concepts reflecting the interconnections between its delimiting aspect and other aspects of reality. In the case of physics, for example, its elementary basic concepts articulate the analogies of prephysical aspects within the structure of the physical aspect, found in phrases such as physical mass (numerical analogy), physical field (spatial), and energy-constancy (the kinematical).

- On the basis of elementary (analogical) basic concepts, successively open for theoretical inspection and analysis, the compound (or complex) basic concepts of a scientific discipline are formed by simultaneously involving distinct analogical basic concepts.

Without exploring the methodology of compound basic concepts in any detail, we may briefly state the result of such an analysis with respect to the nature of norming laws, i.e. of the normative principles guiding human action, such as logical principles, historical principles, social principles, aesthetic principles, jural principles, and so on. Mainly in order to side-step the inherent problems of traditional views of "natural law" (as a universally-valid system of law founded in human reason and holding wherever for all times per se) an account of the nature of a principle ought to distinguish between a principle given as mere starting-point for human action and the diverse, historically changing ways in which such a point of departure could be given a positive shape in specific unique circumstances.

Yet natural law did see something of the underlying (universal, constant) structure of our legal experience, but it distorted its meaning by assuming that those underlying principles are already (for all times and all places) made valid (enforced). No principle in this fundamental ontic sense is valid per se. Every principle requires human intervention in order to be made valid, i.e. no (pre-positive) ontic principle holds by and of itself. Only human beings are capable of "enforcing" them (as Derrida correctly emphasises), ${ }^{14}$ and only the phrase "to enforce the law," or "the enforceability of the law". 
human beings can give a positive form or shape to them. The activity of giving form to underlying principles is sometimes designated as acts of positivising, and the result of such acts are accordingly also known as positivisations. Habermas frequently speaks of "positivising law" ("die Positivierung des Rechts") (see Habermas, $1996: 71 ; 1998: 101,173,180)$. It is this intermediate and dependent position of all positivisations that is reified by the idea of the (logical, lingual or social) construction of the world.

The most basic way to characterise the pre-positive nature of a principle is therefore given in the exploration of the point of entry of the first three modal aspects of reality, namely when we say that a principle is a universal and constant point of departure for human action. ${ }^{15}$ Once this has been said, one can proceed by saying that such a principle can only be made valid (enforced) through human intervention, i.e. through the action of a competent organ with an accountable free will enabling a proper interpretation of the unique circumstances in which the principle should be given a concrete shape (positivised). ${ }^{16}$

The account of a pre-positive principle overlaps with the constitutive elements that ought to be incorporated in an account of natural (physical) laws. Van Fraassen refers to Pierce, who argues that if the "uniformity" intended by Mill merely meant regularity without any real connection implied between events, then his argument will be destroyed (Van Fraassen, 1991:22). The phrase used by Van Fraassen in this context, however, states that a law cannot be "the mere uniformity or regularity itself", for a "law must be conceived as the reason which accounts for the uniformity in nature" (Van Fraassen, 1991:22). The use of the word reason may be interpreted to suggest that laws result from the intellectual human endeavors. Nonetheless, he continues by claiming that a "law must be conceived as something real, some element or aspect of reality quite independent of our thinking or theorising - not merely a principle in our preferred science or humanly imposed taxonomy" (Van

15 The term universal, as we have argued, derives from the spatial awareness of everywhere, the term constant from the core kinematic meaning of uniform flow and the phrase point of departure underscores the unity and distinctness of each principle.

16 Once again the key terms employed in this formulation are derived from diverse modal aspects: organ from the biotic; will (desire) from the sensitive; accountable from the logical-analytical, giving shape (positive form) from the cultural-historical, and interpretation from the lingual modality. 
Fraassen, 1991:22-23). Within the above-mentioned context, this implies that the word reason rather means "cause" - in the sense that a law is the (extra-mental) cause that accounts for the uniformity or regularity of nature. Of course a much easier account would be to state that the regularity of nature concerns its orderliness or lawconformity, entailing that, whatever behaves in law-conformative ways, is subject to a law as order for. For this reason, perhaps the best translation of the German term Gesetzmässigkeit (Dutch and Afrikaans: wetmatig) is subject to law (as done in the translation of Wittgenstein's Tractatus (see footnote 5).

When Van Fraassen discusses the views of Davidson, he points out that, although Davidson does not attempt to define laws, it is nonetheless said "that laws are general statements which are confirmed by their instances" (Van Fraassen, 1991:33). In this case, the distinction between ontic laws and human statements intended to capture conceptually what such laws are all about, collapses. The acceptance of ontic laws does need "markers", i.e. terms helping us to articulate their ontic nature. The mere fact that we speak in the plural about such laws already reflects the constitutive role of the meaning of number (the one and the many) in our understanding of ontic laws. Furthermore, without the conditioning role of the spatial aspect, it cannot be asserted that laws hold everywhere, i.e. that they apply universally. Although Van Fraassen (1991:26) does acknowledge universality as a "mark of lawhood", he does mention, with reference to Armstrong and Lewis, that the "criterion of universality" is "no longer paramount" in a "discussion of laws" (Van Fraassen, 1991:28).17

Of fundamental importance is the distinction between modal laws and type-laws, for it entails an account of the difference between unspecified and specified universality. A modal physical law holds for all kinds of physical entities without any specification, whereas a physical type-law only holds for a limited class of entities, namely those belonging to that type. Such a type-law, for example the law for being an atom, holds universally in the sense that it applies to all atoms, but this universality is specified, since it only holds for atoms (and not for every kind of physical entity). 
In the case of modal laws and type-laws, the reverse side of universality is found in the distinctness of different laws, specified by using the idea of delimitation derived from the primitive meaning of space. Every law has its own domain of application, a specific and distinct sphere within which it obtains. But only when these two elements are combined with the constancy (or uniformity) of a law and its effect (its force, its validity), is it possible to account for the constitutive elements of the compound basic concept of a natural (physical) law.

When Stegmüller discusses the law of causality, he introduces multiple terms closely related to the conditioning role of the first four modal aspects, and in fact approximates closely our idea of compound basic concepts.

Still others might be added to the features we have already mentioned. But since with these the concept of a causal law has already reached such a high level of complexity, let us confine ourselves to them. For faced with the question 'what are causal laws?' we must, in accordance with them, give the following answer: causal laws are quantitative, deterministic, nearby action, succession micro-laws formulated by means of continuous mathematical functions in relation to a homogeneous, isotropic spatio-temporal continuum governed by certain principles of conservation (Stegmüller, 1977:36).

Dooyeweerd did not apply his own transcendental-empirical analysis to the idea of law in general, for he frequently simply (intuitively) states that a law determines and delimits whatever is subjected to it (see Dooyeweerd, 1997:1, 508).

If the distinct scope of laws delimit their unique areas of validity, then it is recommendable not to allow the concept of a natural law to degenerate into an amorphous collection of predicates, such as reflected in a recent factual statement by Stafleu. He says that a law is sometimes hidden behind the name axiom, constant, proposition, rule, relation, thesis, symmetry, theorem, design, pattern, connection, prohibition, comparison, phenomenon or prescription (Stafleu, 2002:39). This list contains elements referring to the law side, the factual side, as well as a mixture of ontic phenomena and the product of human activity. For example, for the sake of convenience, Stafleu calls a mathematical law-conformity ("wiskundige wetmatigheid") such as the theorem of Pythagoras a natural law (Stafleu, 2002:39). 
Inherent to a natural law is its meaning as an order for - and this mode of speech makes an appeal to the unity in the multiplicity of different laws, for without such a unity, laws will clash and not be able to constitute an order of laws (a law-order). The constitutive role of the numerical mode is evident in this concept of order. Furthermore, a law entails its correlate, namely that which is factually subjected to it - and this insight points at the inherent universal scope of a law - derived from the spatial awareness of everywhere (at all places). Without the spatial (dimensional) distinction between above and below, the assumed correlation of law and subject does not make any sense. That the validity of a natural law is not something incidental, is captured by saying that it holds constantly - demonstrating the constitutive role of the kinematic mode. The notion of validity (being in force) derives from the core meaning of the physical aspect, and it has to be incorporated in the concept of a physical (natural) law, because otherwise the ability to say that a law determines what is subjected to it would collapse.

The compound or complex basic concept of a natural law may therefore be formulated as follows;

As a unique, distinct, and universally valid order for what is factually correlated with and subjected to it, a natural law constantly holds (either in an unspecified way as in the case of modal laws or in a specified way as in the case of type laws) within its domain of validity.

However, what is particularly striking in reflections on the relation between law and factuality, is the widely occurring confusion of law and law-conformity.

\section{Law and subject - a new light on the relation between Dooyeweerd and Vollenhoven}

Since the Renaissance the all-pervasive influence of nominalism severely derailed our understanding of the relationship between universality and individuality. One angle of approach has been explored above, namely by drawing a clear distinction between conceptual knowledge and concept-transcending (idea-)knowledge. To my mind this approach is in line with most of the classical analyses and expositions of the controversy between realism and nominalism, where the difference between universality and individuality (the general and the particular) is employed as the crucial distinction. 
When the nature of law and subject is considered in terms of the relationship between universality and individuality what is most striking is found in connection with the difference between the universality of a law and the way in which the determining role of such a law is reflected by what is factually subjected to it.

Vollenhoven and Dooyeweerd both articulated their general idea of God's law in a fairly straight-forward way, without realising that they actually employed modal terms in a concept-transcending manner.18 Vollenhoven, for example, holds that God is sovereign and that God's law is valid for creatures (Vollenhoven, 1967:12, 14; 2005:14, 16).19 Vollenhoven uses the word bewerking (cultivation) in the context of (although in a broader sense than) the historical subject-object relation (Vollenhoven, 1967:135; 2005:139). However, the core meaning of the cultural-historical mode is indeed given in control or formative power. And "having power" is equivalent to the notion of sovereignty. Therefore the affirmation of God's sovereignty merely employs a modal historical term in a concepttranscending way. 20

Likewise the idea of the validity of God's law (its being in force) derives from a concept-transcending use of the meaning of the physical aspect. Vollenhoven experienced severe difficulties in his use of the term boundary in connection with the status and position of God's law. This is clearly seen from the fact that he felt the necessity to qualify his use of the spatial term boundary in such a way that when it is used for God's law, one should not think of spatiality: "With 'boundary' one does not think of spatiality: for spatiality itself belongs to what has been created." Nonetheless connecting the idea of law to the idea of a boundary inevitably results in an idea-use of our spatial intuition. It is simply impossible to escape from a concept-transcending use of spatial terms in the attempt to distinguish between God and creation. This is particularly clear when Vollenhoven holds that law always stands above that for which it is valid (see Vollenhoven, 1967:14). In order to be

18 In general they did not come to terms with the fact that modal terms allow for both a conceptual and a concept-transcending use.

19 The sections quoted from Vollenhoven (1967) are identical to the corresponding sections in Vollenhoven (2005) - explaining why the 2005 page references are added to the 1967 references.

20 The Bible uses many other "modal terms" in its revelation of God - such as that God is life, God is love, God is just, and so on. Why single out just one of them? 
consistent Vollenhoven also had to disqualify the term above - it is not supposed to refer to something spatial because the aspect of space belongs to what has been created. Yet, saying that God's law is elevated above creation begs the question, for the negation of spatiality is actually accomplished through an idea-use of the spatial term above! This demonstrates that the negation of spatiality is achieved by employing the meaning of space!21

Once a distinction is drawn between conceptual knowledge and concept-transcending knowledge, it is possible to note a strong convergence in the views of Vollenhoven and Dooyeweerd regarding the place of God's law. When Vollenhoven highlights validity as the distinctive property of God's law, his stance is not far from Dooyeweerd's position, for the latter constantly speaks of the universal validity of God's law. 22

We can proceed by mentioning that the two philosophers are quite close in their concept-transcending modes of speech in respect of idea-usages of physical terms such as encountered in their belief that God's law has an effect on what is subjected to it - God's law is valid, it holds in the sense of determining creatures (Dooyeweerd: bepaal; Vollenhoven: bepaaldheid - determine and determination). But since I have discussed these issues extensively in a different context (see Strauss, 2006), ${ }^{23}$ we may terminate our discussion with a concluding remark.

21 When Van der Walt explains his Biblically shaped ontology, the same vicious circle surfaces. His claim is that one cannot speak of God in spatial terms. Why not? Because "God is elevated above space" (Van der Walt, 1976:128). Once again the phrase "elevated above" reveals its modal seat within the spatial aspect, and this implies that only through the employment of spatial terms is it possible to claim that God transcends (!) space.

22 The same applies to the two options apparently dividing the views of Vollenhoven and Dooyeweerd regarding the terms above and side, because in both cases we simply meet spatial terms employed in concept-transcending ways.

23 An important difference between Vollenhoven and Dooyeweerd is given in their respective acceptance and denial of universality at the factual side of reality. Dooyeweerd identifies law and law-conformity (wet and wetmatig) and in doing so strips factual reality of its universality (a nominalistic after-effect in his thought). Vollenhoven explicitly rejects the identification of law and law-conformity (see Vollenhoven, 2005:16). Dooyeweerd (and Stafleu) speak of the individual factual side of reality (Stafleu, 1968:304; see Stafleu, 1989:25, 26, 44, $83 ; 2002: 16)$ that is correlated with law and law-conformity. They are both confused about the relationship between law and law-conformity. 


\section{Concluding remark}

The history of reflection on the relationship between law and individuality helped us to articulate a systematic view on the nature of normative laws (principles) and natural laws - acknowledging that a sound analysis has to understand what elementary (analogical) and compound basic concepts are about. The close connection between universality and individuality indeed paved the way for an understanding of the destructive role of nominalism in modern philosophy and the denial of universality outside the "human mind" eventually leading to the Kantian view of human understanding as the formal law-giver of nature. The mirror-side of this rationalistic element of modern nominalism is manifest in the rise of historicism and the eventual linguistic turn - exploring the irrationalistic part of nominalism. Discerning these issues did benefit from the distinction between conceptual knowledge and concept-transcending knowledge - a distinction that was finally made fruitful for a brief assessment of some differences and similarities in the thought of Dooyeweerd and Vollenhoven.

\section{List of references}

ARISTOTLE. 2001. The basic works of Aristotle. Edited by Richard McKeon with an introduction by C.D.C. Reeve. (Originally published by Random House in 1941.) New York: The Modern Library.

BENNETT, J. 1974. Kant's Dialectic. Cambridge: Cambridge University Press.

BORSCHE, T. 1976. Individuum, Individualität. (In Ritter, J., Gründer, K. \& Gabriel, G., Reds. Historisches Wörterbuch der Philosophie. Teil 4. BaselStuttgart: Schwabe. S. 310-323.)

CASSIRER, E. 1911. Das Erkenntnisproblem in der Philosophie und Wissenschaft der neueren Zeit. Teil 2. Berlin: Bruno.

CASSIRER, E. 1953. Substance and function. (First edition of the English translation of Substanzbegriff und Funktionsbegriff. 1923; First German edition 1910.) New York: Dover.

CASSIRER, E. 1957. Das Erkenntnisproblem in der Philosophie und Wissenschaft der neueren Zeit. Stuttgart: Kohlhammer.

CICERO, M.T. 1978. Res publica: Roman politics and society according to Cicero. Selected and translated by W.K. Lacey \& B.W.J.G. Wilson. Bristol: Bristol Classical Press.

CICERO, M.T. 1991. De officiis, On duties. Ed. by M.T. Griffin \& E.M. Atkins. Cambridge: Cambridge University Press.

DE VLEESCHAUWER, H.J. 1952. Handleiding by die studie van die logika en die kennisleer. Pretoria: Moerau.

DERRIDA, J. 2002. Force of law: the mystical foundation of authority. (In Anidjar, Gil, ed. Acts of religion. New York: Routledge. p. 230-298.)

DESCARTES, R. 1965. A discourse on method, mediations and principles. Translated by John Veitch; introduced by A.D. Lindsay. London: Everyman's Library. 
DIELS, H. \& KRANZ, W. 1959/1960. Die Fragmente der Vorsokratiker. Teil 1-3. Berlin: Weidmannsche Verlagsbuchhandlung.

DOOYEWEERD, H. 1997. A new critique of theoretical thought: collected works of Herman Dooyeweerd. A-Series, vols. 1-4. General editor: D.F.M. Strauss. Lewiston: Edwin Mellen.

GUTHRIE, W.K.C. 1962. A history of Greek philosophy. Volume 1: The earlier Presocratics and the Pythagoreans. Cambridge: Cambridge University Press.

HABERMAS, J. 1996. Between facts and norms: contributions to a discourse theory of law and democracy. Translated by William Rehg. Cambridge: MIT.

HABERMAS, J. 1998. Faktizität und Geltung: Beiträge zur Diskurstheorie des Rechts und des demokratischen Rechtstaats. 2. Ausg. Frankfurt am Main: Suhrkamp.

HARTMANN, N. 1957. Kleinere Schriften. Teil 2. Berlin: De Gruyter.

HEGEL, G.W.F. 1957. Sämtliche Werke. Teil 2. Stuttgart: Friedrich Frommann.

HERDER, J.G. 1877. Red.: Bernhard Suphan. Herders sämmtliche Werke (1877-1913). Berlin: Weidmann.

HERDER, J.G. 1978. Johann Gottfried Herder: Abhandlung über den Ursprung der Sprache, Text, Materialen, Kommentar. Herausgeber Wolfgang Proß. München: Carl Hanser.

HEROLD, N. 1974. Der Gesetzesbegriff in Philosophie und Wissenschaftstheorie der Neuzeit. (In Ritter, J., Gründer, K. \& Gabriel, G., Reds. Historisches Wörterbuch der Philosophie. Teil 4. Basel-Stuttgart: Schwabe. S. 501-514.)

HESIOD. 1962. Erga. 2. Ausg. Erklärt von Ulrich von Wiliamowitz-Moellendorff. Berlin: Weidmann.

JONES, J.W. 1956. Historical introduction to the theory of law. Oxford: Clarendon.

KANT, I. 1781. Kritik der reinen Vernunft. 1. Ausg. (References to CPR A.) Hamburg: Meiner.

KANT, I. 1786. Metaphysische Anfangsgründe der Naturwissenschaft. Herausg. Wilhelm Weischdel. Darmstadt: Wissenschaftliche Buchgesellschaft.

KANT, I. 1956 [1787]. Kritik der reinen Vernunft. 2. Ausg. Hamburg: Meiner.

KANT, I. 1969 [1783]. Prolegomena einer jeden künftigen Metaphysik die als Wissenschaft wird auftreten können. Hamburg: Meiner.

KOBUSCH, Th. 1976. Individuum, Individualität. (In Ritter, J., Gründer, K. \& Gabriel, G., Reds. Historisches Wörterbuch der Philosophie. Teil 4. BaselStuttgart: Schwabe. S. 299-304.)

MEINECKE, F. 1965. Die Entstehung des Historismus. Teil 3. Red.: Carl Hinrichs. München: Oldenburg.

NEWTON, I. 1955 Mathematical principles of natural philosophy. Tr. by Andrew Motte, rev. by Florian Cajori. Cicago: Encyclopaedia Britannica.

OEING-HANOFF, L. 1976. Individuum, Individualität - Hoch- und Spätskolastik. (In Ritter, J., Gründer, K. \& Gabriel, G., Reds. Historisches Wörterbuch der Philosophie. Teil 3. Basel-Stuttgart: Schwabe. S. 304-310.)

PLOTINUS, 1956. Translated by Stephen MacKenna. The Enneads. London: Faber \& Faber. 
PLUMPE, G. 1974. Die religiöse und theologische Bedeutung des Gesetzesbegriffs. (In Ritter, J., Gründer, K. \& Gabriel, G., Reds. Historisches Wörterbuch der Philosophie. Teil 3. Basel-Stuttgart: Schwabe. S. 494495.)

STAFLEU, M.D. 1968. Individualiteit in de Fysica. (In: Stellingwerf, J. Reflexies: essays dedicated to Mekkes. Amsterdam: Buijten \& Schipperheijn. p. 287305.)

STAFLEU, M.D. 1989. De verborgen structuur: wijsgerige beschouwingen over natuurlijke structuren en hun samenhang. Amsterdam: Buijten \& Schipperheijn.

STAFLEU, M.D. 2002. Een wereld vol relaties. Amsterdam: Buijten \& Schipperheijn.

STEGMÜLLER, W. 1977. Collected papers on epistemology, philosophy of science and history of philosophy. Volume 2. Dorcrecht-Holland: Reidel.

STICH, S.P., ed. 1975. Innate ideas. Berkeley: University of California Press.

STRAUSS, D.F.M. 1982. The place and meaning of Kant's Critique of pure reason (1981) in the legacy of Western philosophy. South African journal of philosophy, 1:131-147.

STRAUSS, D.F.M. 2000. Kant and modern physics: the synthetic a priori and the distinction between modal function and entity. South African journal of philosophy, 2(1):26-40.

STRAUSS, D.F.M. 2006. Appropriating the legacy of Dooyeweerd and Vollenhoven. Journal for Christian scholarship, 42(4):23-56.

VAN DER WALT, B.J. 1976. Die waarde van 'n Skrifmatige ontologie. Tydskrif vir Christelike wetenskap, 12(3 \& 4):124-131.

VAN FRAASSEN, B.C. 1991. Laws and symmetry. Oxford: Clarendon.

VAN ZYL, D.H. 1989. Justice and equity in Cicero: a critical evaluation in contextual perspective. Bloemfontein: University of the Free State. (Unpublished D.Litt. thesis.)

VOLLENHOVEN, D.H. 1967. Isagoogè Philosophiae. Amsterdam: Edition of the Philosophical Institute at the Free University.

VOLLENHOVEN, D.H. 2005. Isagôgè Philosophiae: introduction to philosophy. Translated from the Dutch by John H. Kok, edited by John H. Kok \& Anthony Tol. Dordt: Dordt College Press.

VON WEIZSÄCKER, C.F. 2002. Große Physiker, von Aristoteles bis Werner Heisenberg. München: Deutscher Taschenbuch Verlag.

WITTGENSTEIN, L. 1966. Tractatus Logico-Philosophicus. London: Routledge \& Kegan Paul.

\section{Key concepts:}

concept-transcending knowledge

conceptual knowledge

individuality

law

law-conformity

universality 


\section{Kernbegrippe:}

begripskennis

begripstransenderende kennis

individualiteit

wet

wetmatigheid 
